\title{
THE USE OF GEOGRAPHIC INFORMATION SYSTEMS IN THE DETERMINATION OF AREAS AT RISK OF DENGUE IN THE SÃO PAULO STATE
}

\author{
Thiago Salomão de AZEVEDO ${ }^{1}$ \\ Maria Anice Mureb SALLUM²
}

\begin{abstract}
The Dengue Virus is a Flavivirus transmitted to humans by Aedes mosquitoes. This arbovirus is responsible for one of the main problems of global public health, because it is estimated that over 80 million people are infected by it every year. In Brazil there are reports that dengue fever epidemics have been present from the beginning of the twentieth century. However, the first dengue fever outbreak documented in the country occurred in 1982. From that point on, the Brazilian territory has been plagued by several of these epidemics. Among the various attempts to elucidate the factors that influence the dynamics of the transmission of dengue fever, the Brazilian Ministry of Health reorganized, in 2002, the National Plan to Combat Dengue Fever and instituted a normative procedure by which the areas affected by this epidemic should be mapped. The use of geographical information systems is a powerful tool for the spatial analysis of risk; by this means the spatial distribution of the event can be described and associations between an event and its determinants can be observed. Based on these assumptions this study aims to determine the geospatial patterns of dengue fever outbreaks in São Paulo State, Brazil. This region has been seriously affected by successive epidemics during the last 15 years. We have used conventional and spatial analytical tools (geostatistics analysis) to discern the patterns of the epidemic scenarios. Results showed that dengue fever outbreaks have affected two principal areas of risk: one located in the northwest and the other in the central-south portion of the São Paulo State.
\end{abstract}

Key words: Dengue Fever. Geographic Information Systems. Geostatistics. São Paulo State.

\footnotetext{
${ }_{1}$ Pós-doutorando, Departamento de Epidemiologia (Faculdade de Saúde Pública - Universidade de São Paulo, USP) - Avenida Doutor Arnaldo 715, CEP 01246-904, São Paulo (SP), Brazil. Fone: +55-11-3061-7951 - E-mail: azevedots@gmail.com

2 Departamento de Epidemiologia (Faculdade de Saúde Pública - Universidade de São Paulo, USP) - Avenida Doutor Arnaldo 715, CEP 01246-904, São Paulo (SP), Brazil. Fone: +55-11-3061-7951 - E-mail: masallum@usp.br)
} 


\section{Resumo}

\section{Uso de sistemas de informação geográfica na determinação das áreas de risco de dengue no Estado de São Paulo}

O vírus da dengue é um arbovirus do tipo flavivírus que é transmitido aos seres humanos por mosquitos do gênero Aedes. Esta enfermidade é responsável por um dos principais problemas de saúde pública mundial, pois estima-se que mais de 80 milhões de pessoas são infectadas a cada ano. No Brasil, existem relatos de que as epidemias de dengue estavam presentes desde o início do século XX. No entanto, a primeira epidemia de dengue documentada no país ocorreu em 1982. A partir dessa data, o território brasileiro vem sofrendo sucessivas epidemias. Entre as várias tentativas de elucidar os fatores que influenciam a dinâmica de transmissão da dengue, o Ministério da Saúde do Brasil, em 2002, reestruturou o Plano Nacional de Combate à Dengue e instituiu uma normativa que estabelece que as áreas afetadas por esta epidemia devem ser mapeadas. Assim, o uso de sistemas de informação geográfica tornou-se uma ferramenta poderosa na análise espacial do risco e na distribuição espacial das epidemias de dengue. Em virtude das afirmações acima mencionadas, este estudo tem o objetivo de determinar os padrões geoespaciais dos surtos de dengue no Estado de São Paulo, Brasil. Para realizar tal procedimento, foram utilizadas ferramentas analíticas convencionais e espaciais (análise geoestatística) para tratar padrões dos cenários desta epidemia. Os resultados mostraram que os surtos de dengue possuem duas áreas de risco importantes. Uma área está localizada no noroeste e a segunda área esta localizada na porção centro-sul do Estado de São Paulo.

Palavras-chave: Dengue. Sistemas de Informação Geográfica. Geoestatística. Estado de São Paulo.

\section{INTRODUCTION}

Dengue is one of the main global public health problems. According to the World Health Organization (WHO) it is estimated that more than 80 million people are infected by it every year. This worrying situation led to the WHO's declaring dengue to be the most significant arbovirus in the world today, seeing that about 2.5 billion people live in areas of risk where this disease occurs in endemic form (SIQUEIRA et al., 2010).

Although there are reports of probable dengue epidemics which occurred in the XIXth century (SOUZA, 2008), the reappearance of dengue became a grave Public Health problem in Brazil as from the 1970s. The first epidemic documented in the country occurred in Boa Vista, Roraima, in 1982. Later, in 1986, dengue reappeared in epidemic form in the states of Rio de Janeiro, Ceará and Alagoas (SIQUEIRA et al., 2010).

In the state of São Paulo (SP) the beginning of the transmission occurred in 1987, in the municipalities of Guararapes and Araçatuba, which presented, respectively, 30 and 16 cases. After an interval, at the end of 1990 , dengue returned as an autochthonous disease in the region of Ribeirão Preto, provoking an epidemic which spread through more than 50 municipalities (BARBOSA et al., (2012). As from that date, this arbovirus has been provoking successive epidemics in the territory of the state of São Paulo (SÃO PAULO, 2010).

Initially restricted to the regional centers, the area in which dengue occurred expanded throughout the São Paulo state in the following decades (BARBOSA et al, 2012). One of the factors responsible for the increase in the number of epidemics, was 
the simultaneous circulation of 4 serotypes (DEN 1-4) (FORATTINI, 2002). This epidemiological configuration led to an increase in the number of persons susceptible, so much so that at the beginning of the 2000s, notifications began to appear of hemorrhagic dengue fever and serious cases also among children (SÃO PAULO, 2010). Further, the disorganization of the territorial landscape together with the absence of urban planning have also contributed to the expansion of this epidemic in the state, because the lack of public sanitation and the inadequate habits of the population give rise to the creation of a large number of sites suitable for the larval development of the species Aedes (Stegomyia) aegypti (Linnaeus, 1762), thus increasing the risk of epidemic outbreaks (LAFFERTY, 2009; ALI et al., 2003; HEUKELBACH et al., 2001).

Although the efforts made to contain the dengue epidemic were intense throughout the state, many of the measures adopted were applied haphazardly. As examples, we may mention the campaigns which were undertaken during the periods of more intense transmission and the measures adopted which sought to reduce the disease-load during the epidemic moment. In the periods of greater mobilization for dengue control, the means of mass communication are active in making the population aware of the problems and encouraging health managers to adopt intense control actions. However, after the epidemic when vector intensity diminishes and infestation is, therefore, lower, the financial resources are generally destined to the control of other public health problems. The discontinuity of the programs then leads to a reduced participation of the population and communities in the activities dedicated to the control of the vector mosquito. In consequence the density of the insect increases and with the advent of higher temperatures, Aedes aegypti once again proliferates rapidly and a new epidemic cycle is begun (SIQUEIRA, 2010).

Thus, in the attempt to elucidate the factors which interfere in the dynamics of dengue transmission, the Ministry of Health re-organized the National Plan to Combat Dengue (o Plano Nacional de Combate a Dengue - PNCD) and instituted, in 2002, a new normative procedure called "Dengue Risk" ("Risco Dengue", BRASIL, 2012). This institutional measure had as its purpose the mapping of the areas in which the number of cases and mosquito vector infestation was greater. Thus various studies were undertaken using geoprocessing techniques as a means of visualizing the areas of risk (BARBOZA et al, 2014; PIOVEZAN et al, 2014; FAVARO et al., 2013; FLAUZINO et al., 2009; FERREIRA; CHIARAVALLOTI NETO, 2007; MONDINIE; CHIARAVALLOTI NETO, 2007; HINO et al, 2006; BARCELLOS et al. 2005; ALI et al., 2003). In accordance with the above-mentioned authors, the importance of geoprocessing when applied in epidemiological studies lies mainly in the identification of the areas of the risk of the exposed population and in the monitoring of the dissemination of the complaints. However, Araujo et al. (2008) observe that these studies are being applied mainly on the local scale, that is to say, they take the individual city as their unit of study.

In the literature, studies which involve mapping of the possible areas of risk of infestation by the vector mosquito and of dengue on a regional scale are few. Among those found, the studies of Barbosa et al (2012); Glasser and Gomes (2000 and 2002) are noteworthy. It is possible to verify in those studies the geographical extent of the areas, in the State of São Paulo, infested by Aedes albopictus and Aedes aegypti. As regards the mapping of cases we may highlight the study undertaken by Ferreira (2003), who mapped the dengue epidemic which occurred in 2001 in the municipalities of the intermediate region (mesoregião) of São José do Rio Preto - SP and of Azevedo (2013), who mapped the rate of insalubrities in regard to dengue for the administrative region of Campinas for the period from 2005 to 2009. Other studies which deserve mention are that of Catão and Guimarães (2013), who mapped the intensity of the dengue epidemics in the State of São Paulo in the period from 2000 to 2010; the research conducted by Barcellos and Lowe et al. (2014), who ascertained the influence, both in space and time, of the climatic seasonal variation in the risk of the occurrence 
of dengue epidemics in the Brazilian micro-regions during the period from 2001 to 2008, and the study conducted by Duque et al. (2010), who correlated in terms of space and time the occurrences of infestation of the Aedes aegypti mosquito with the number of cases of persons attacked by dengue in the State of Paraná.

In the attempt to make good this lack and considering spatial heterogeneity as one of the primordial factors in the establishment of these epidemics, this study seeks, on a broader scale, to identify the areas of risk of the dengue epidemics which occurred in the State of São Paulo during the period from 2000 to 2015. For this purpose, the most susceptible areas to the occurrence of this arbovirus were identified by means of the use of geographic information systems and geostatistics principles.

Beyond that, this study also brings out the importance of the use of these geocomputational tools applied to the mapping of endemic diseases, because the results obtained may be used by government managers in their adoption of more efficient mitigating measures, both in the control of the vector and in the prevention of the disease.

\section{MATERIAL AND METHODS}

Data relating to autochthonous cases of dengue were used in the analyses, as notified annually during the period from 2000 to 2015, distributed by the municipality of the State of São Paulo, as obtained from the Centre of Epidemiological Vigilance (Centro de Vigilância Epidemiológica - CVE) of the State of São Paulo.

First, the incidence of cases was calculated on the basis of the information given by Laurenti et al. (1987) and Fotherringham et al. (2000). The coefficient of incidence reflects the intensity of morbidity within a given population (LAURENTI et al., 1987).

$$
I=\frac{\text { number of new cases }}{\text { population at risk }} \times 100.000
$$

were: $I$ is the incidence

After the calculation of the incidence of the cases of dengue, the municipalities which presented outbreaks of the disease were determined. The outbreak estimate proposed by Waldman (1998) was adopted for this. This procedure transforms the data into a binary indicator which was used to model the maps of the probability of occurrence of dengue outbreaks for the period studied.

The methodological procedure for the sampling took as its basis the map of the municipalities of SP. Initially the central geographical coordinates of each municipality were identified and this allowed us to identify 645 sampling points (Figure 1).

For the spatial analysis of the dengue outbreaks in the State of São Paulo, two geostatistics procedures were adopted. The first of them was to map the tendency of the occurrences of the dengue outbreaks.

The data were, first, exported to the Software Surfer (GOLDEN SOFTWARE, 1995). This procedure had the purpose of transforming the data-bank into an image which showed a surface with a tendency of a regional nature. 


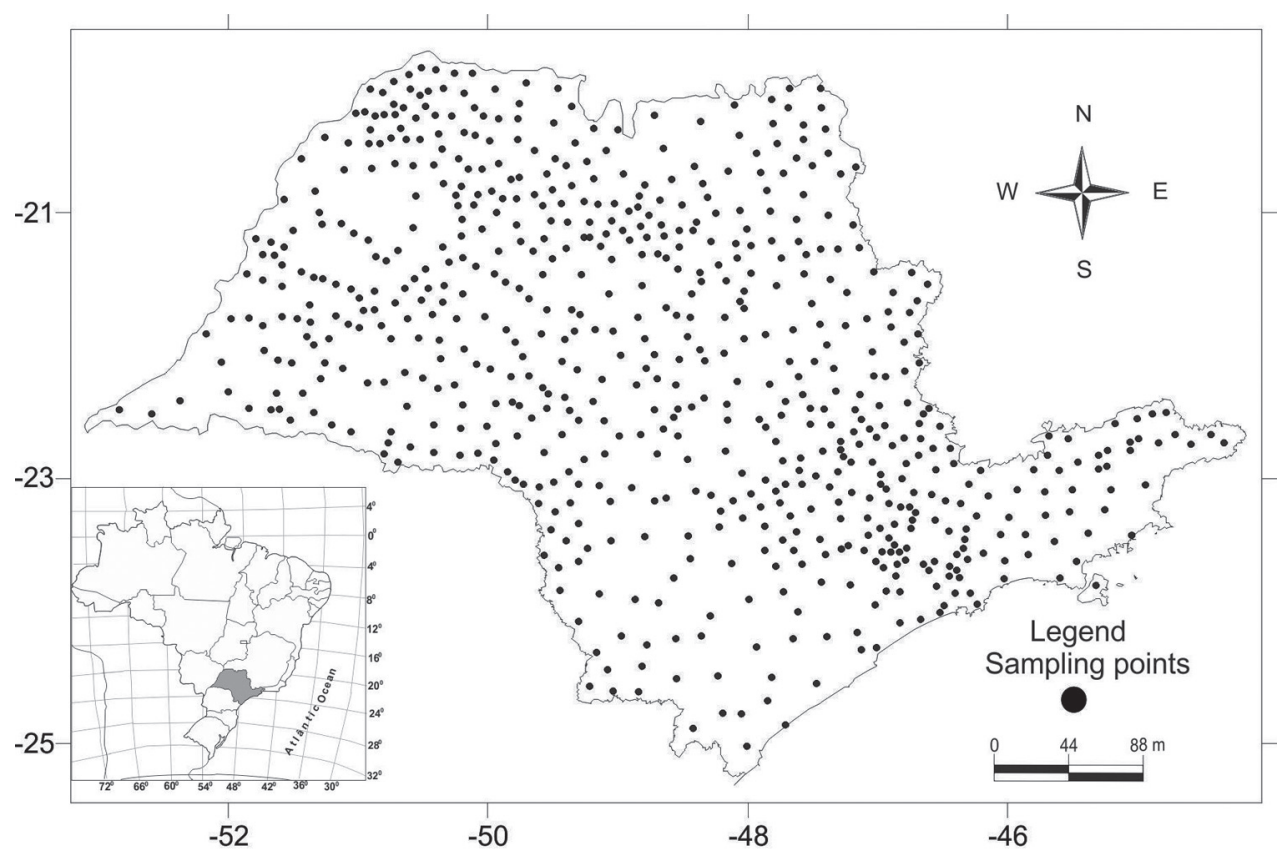

Figure 1 - Location of the study area

This mapping technique consists of a method by which a continuous surface is adjusted to the values $Z$ (outbreaks) as a linear function of the coordinates $X Y$ of the points sampled, by means of a non-orthogonal polynomial equation (PFEIFFER et al. 2008). Thus, seeking the best possible adjustment of the information, a cubic surface of the third degree was adopted (LAWSON, 2008). The final product of this procedure was the construction of an isopletic cartogram which presented the tendency of spatial distribution of the dengue outbreaks in the São Paulo State.

After this procedure, the second stage was the mapping of the areas of the greatest probability of occurrence of the outbreaks by means of indicative kriging. To carry out this process it was necessary first to verify the spatial behavior of the dengue outbreaks by means of variographic analysis. This analysis was compiled on the basis of the construction of the semivariogram which shows the degree of spatial dependence of the samples. To express this relation, the $x$ axis is defined as being the vector of distance, whereas the $y$ axis gives the variance between the sampled points (ISAAKS; SRIVASTAVA, 1989).

The obtaining of the semivariogram is the most important part of the geostatistics studies because it is a part of the so-called structural analysis and it is necessary for the verification of the continuity of the data, that is to say, this analysis establishes whether the data possess a nugget effect (YAMAMOTO; LANDIM, 2013). The existence of such an effect makes it impossible for the krigagem method to be used, because it is then assumed that the data contain measurement errors.

Thus the kriging method can only be used if the data set meets the pre-requisites described above. This process of the estimation of the values of variables distributed in space is made on the basis of adjacent values by means of regression analysis 
which minimizes the estimated variance on the basis of a stochastic model (CARVALHO; CÂMARA, 2004).

Thus, on the basis of the variographic model obtained, the interpolation was carried out by the indicative kriging method. The result of this operation was the generation and compilation of a map of the probability of the occurrence of dengue outbreaks in the São Paulo State in the period from 2000 to 2015.

\section{RESULTS}

The rise of the epidemics in São Paulo State may have various causes. For Camara et al. (2007), the introduction of different serotypes of the virus was the main factor responsible for the increase in the incidence of the disease. During the period from 2000 to 2015, the state of São Paulo was ravaged by four dengue epidemics. In that period, when we observe the epidemics in relation to the municipalities in which epidemic outbreaks occurred, we can discern three distinct moments (Figure 2).

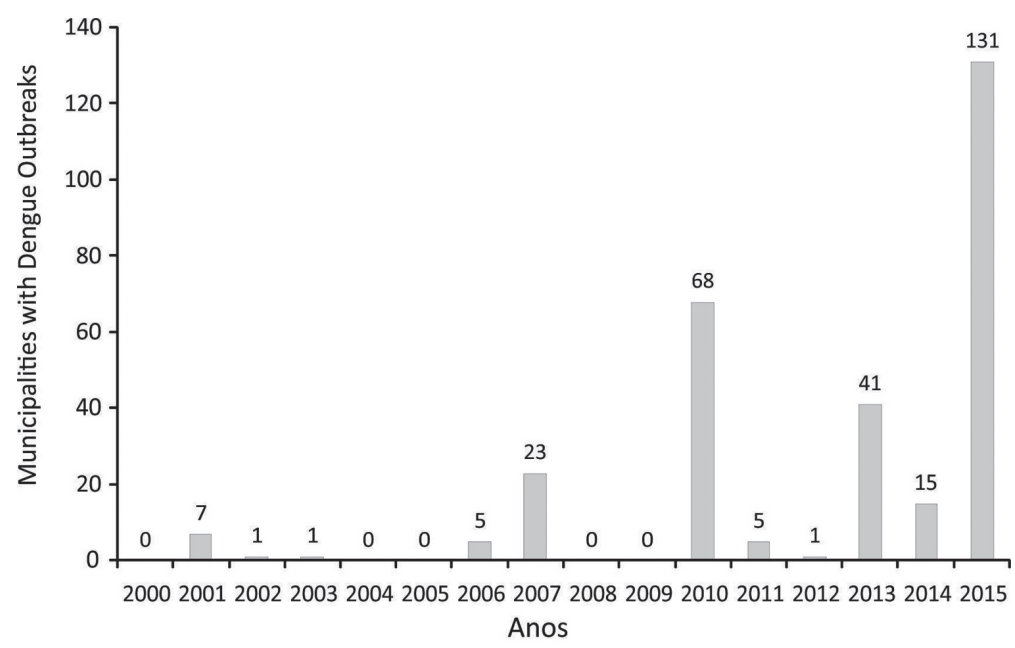

Figure 2 - Historical evolution of dengue outbreaks in the São Paulo State from 2000 to 2015 period

In the 1990s, beyond the serotype 1 which circulated in the state, the introduction of serotype 2 and the expansion of the area of the occurrence of the Aedes aegypti mosquito were central to the occurrence of the epidemics. In the 2000s, the state of São Paulo was affected by dengue epidemics of larger proportions than those which had occurred in previous years. The introduction of serotype 3 in mid-2002 led to the dissemination of the infections in the urban centers because more people had become susceptible to dengue (CATÃO, 2012).

Thus, in the period from 2000 to 2007, few municipalities presented epidemic outbreaks. So much so that the year 2001 was the first year that presented this kind of event. As from 2007, the year in which a great dengue epidemic occurred in the 
state São Paulo, the municipalities where outbreaks occurred began to present a highly specific cyclic epidemic pattern. Each three years, the São Paulo state was swept by a dengue epidemic. Thus, the second period which corresponds to the space of time from 2007 to 2013 was characterized by the occurrence of successive epidemics in the years 2007, 2010 and 2013.

However, a third dengue epidemic moment corresponds to the period from 2014 to 2015, in which there are evidences that these epidemics are increasing in extent and frequency, because the epidemic cycle was occurring at an unprecedented speed. This period was characterized by the greatest dengue epidemic ever recorded in São Paulo, 131 of its municipalities registering outbreaks in 2015.

As regards the spatial distribution of the dengue epidemic, figure 3 showed the historical tendency of the occurrence of epidemic outbreaks in the São Paulo State. It may be noted from this figure that the tendency is for the outbreaks to occur with ever greater frequency in areas of the state where the temperatures are higher. The first region is situated in the northern and north-eastern parts of the state, being restricted to the Western Plateau of the state of São Paulo (Planalto Ocidental Paulista), spreading southwards towards the transitional areas of the Peripheric Depression (Depressão Periférica). The second region, of smaller size, is situated along the whole of the littoral of the state, extending northwestwards as far as the Atlantic Plateau (Planalto Atlântico) and the Paraíba river Valley (Vale do Paraíba).

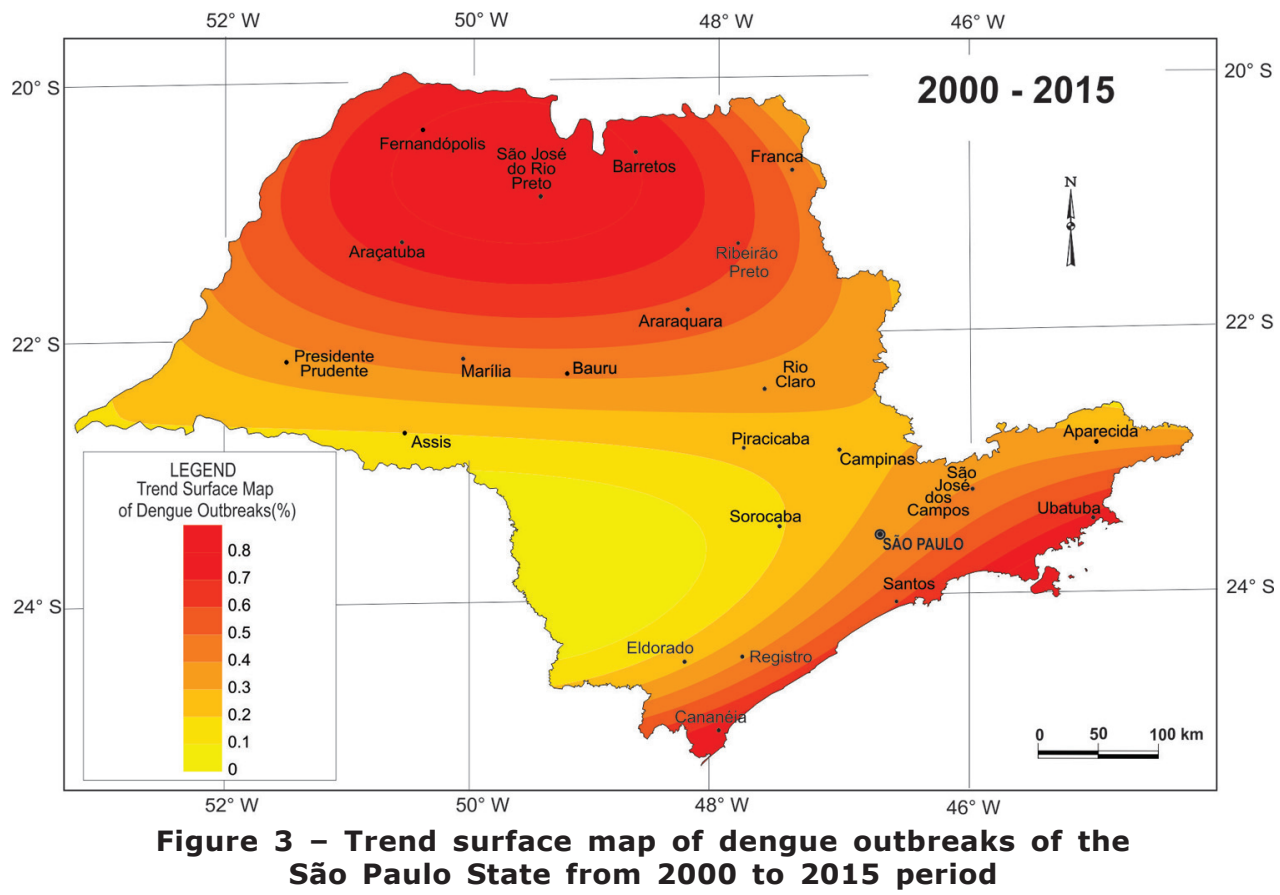

The lowest surface values of the tendency indicate the areas of the upper basin of the river Paranapanema, of the Plateau of Poços de Caldas, of the Paulistano Plateau and of the Serra da Mantiqueira. The probable explanation for this configuration is that 
these areas are situated at a higher altitude and closer to the sub-tropical zone, coming therefore with greater frequency under the influence of cold fronts, indicating possible topographical barriers.

With regard to the spatial and temporal distribution of dengue epidemics in the São Paulo State, the variographic map (Figure 4) shows the spatial variability of the epidemic outbreaks. It is possible to see from this figure that the agreement found was the Gaussian with a reach of 0.481 decimal degrees.

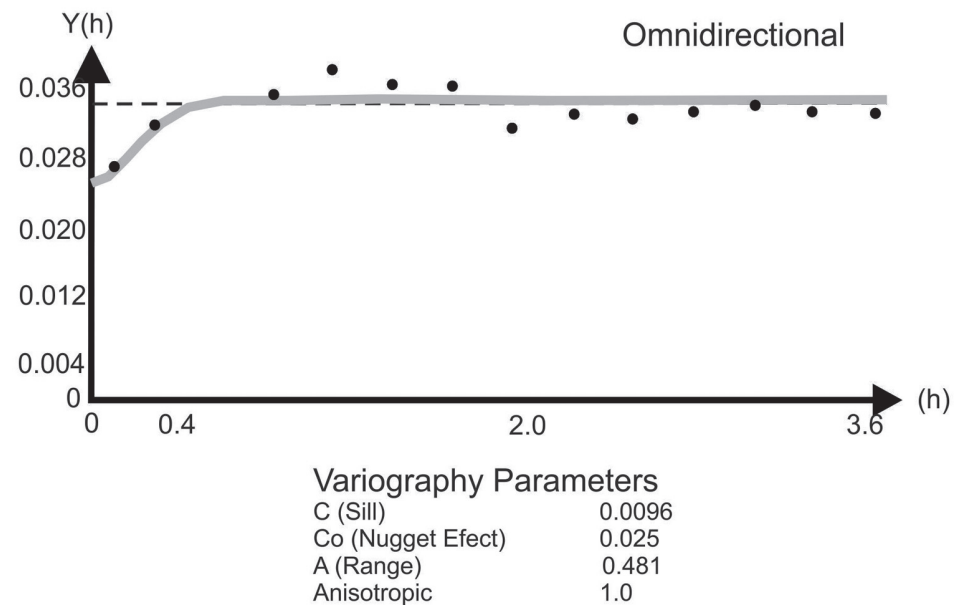

Figure 4 - Semivariogram of dengue outbreaks from 2000 to 2015 period

This information permits us to trace the limits of influence of interest, thus establishing that the structure of spatial auto-correlation was stipulated as being 0.481 decimal degrees of latitude. Converting this value into a metric unit of distance, we find that the autocorrelation of the dengue epidemics is of approximately $53.33 \mathrm{~km}$. These results corroborate those of the study undertaken by Barbosa et al. (2012), who specified a radius of $50 \mathrm{~km}$ as determining the limit of the geographical influence of transmission of this complaint, between the municipalities denominated regional poles and their neighboring municipalities.

Figure 5 shows the map of the probability of the occurrence of dengue outbreaks in the state of São Paulo (figure 5). We may first note that the greatest frequencies of occurrence of the outbreaks are concentrated in the littoral and in the mid-west/ northwest/northeast region of the territory of the state. These areas are seen to be the most favorable for the occurrence of epidemic outbreaks, as they are of low altitude and higher temperatures.

The cities of large and intermediate demographic size of these two regions, called regional centers, present the greatest probability of the occurrence of outbreaks, and include Fernandópolis, Barretos, Ribeirão Preto, São José do Rio Preto, Araçatuba, Marilia, Campinas, Assis and Santos. 


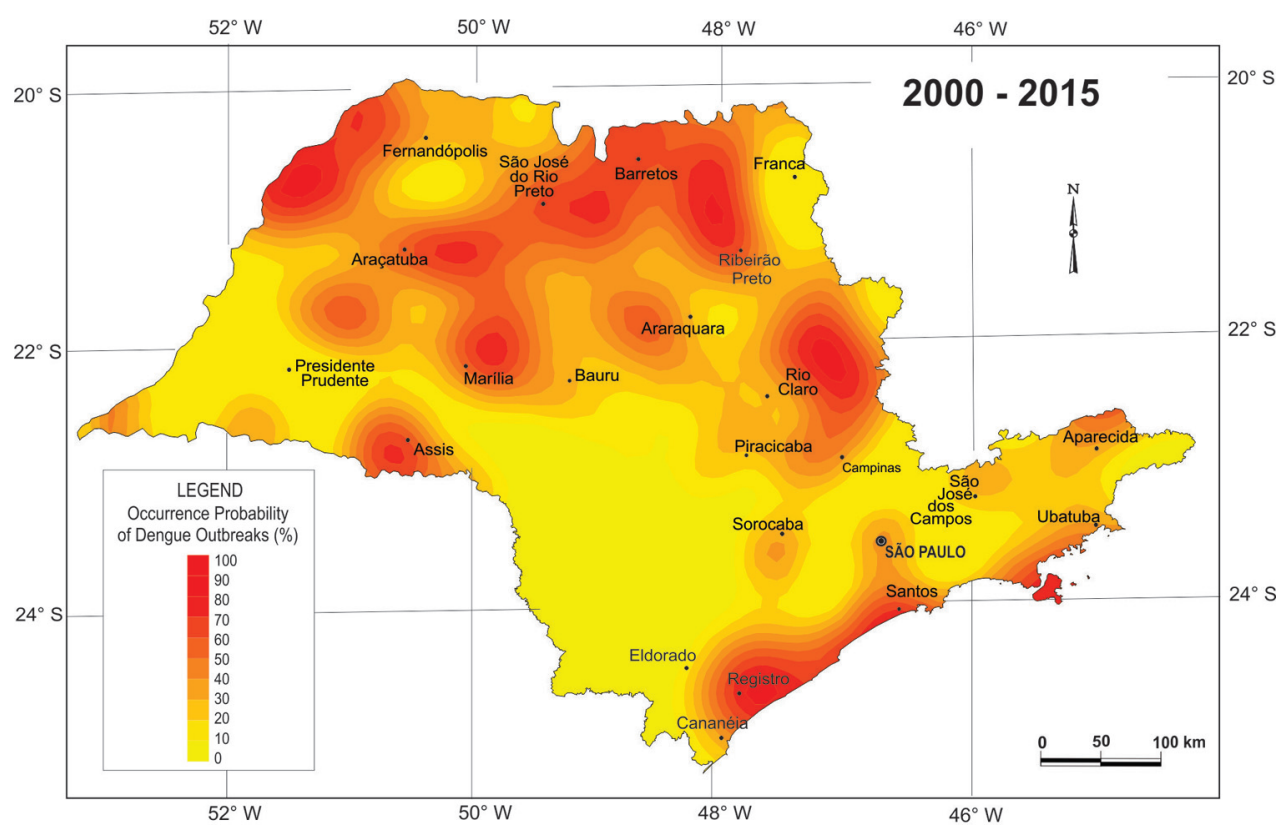

Figure 5 - Map of occurence probability of dengue outbreaks in São Paulo State from 2000 to 2015 period

On the other hand, we note that the parts of the State in which the probability of the occurrence of outbreaks is lower are those where the temperature is milder, those with higher altitudes, and those of lower population density. These regions are situated, respectively, in the Serra da Mantiqueira - a branch of the Serra do Mar, in Alto do Paranapanema, and in the middle stretches of the rivers Ribeira de Iguape and Paranapanema.

\section{DISCUSSION}

The explanations for the epidemiological configuration of dengue in the state of São Paulo during the period from 2000 to 2015 may be related to the historical geographical context of the areas of infestation, of demographic density and of the migratory population of the territory of the state.

In relation to the history of the infestation of the dengue mosquito vector, in accordance with Glasser and Gomes $(2000 ; 2002)$ the northwest of the state is known as the oldest infested area. This area has been invaded by the mosquito Aedes aegypti from the infested municipalities of the states of Minas Gerais and Mato Grosso do Sul, since the mid-1980s. These authors also draw attention to the fact that these regions present the highest temperatures in the state. These conditions may be influential in the transmission of dengue, seeing that the concentration of rainfall in a hightemperature environment, creates an excellent situation for the reproduction and dispersion of Aedes aegypti, leading thus to the epidemic outbreaks (WATTS et al. 1987; CONSOLI; OLIVEIRA, 1998; CÂMARA et al, 2009). 
The municipalities which are situated in the Valley of the Rio Paraíba: São José dos Campos, Jacareí and Aparecida do Norte, together form another area of note in the state. In these places, according to Glasser e Gomes (2000), the existence of communes infested with the mosquito Aedes aegypti is due to municipalities located in the state of Rio de Janeiro (RJ), which may have spread the occurrence of foci in these places.

In the west and southwest of the state of São Paulo, according to Glasser e Gomes (2000), the infestation is due to the existence of infested municipalities in the states of Paraná (PR) and Mato Grosso do Sul (MS), as for example Foz do Iguaçu, Maringá, Novo Mundo, Ponta Porã and Campo Grande, among others. For the authors quoted, the infestation may be related to the existence of regional poles which provided a greater movement of people and, consequently contributed to the establishment of the vector mosquito.

In the region of the Santos Bay (Baixada Santista), infestation by Aedes aegypti occurred as a result of the highly favorable conditions for the establishment of the disease and its vector, which spread rapidly through this region due to its climatic conditions, and to the flow of population related to tourist and socio-economic activities. Within this context, the role of the main highways of the state in their canalization of the flow and its concentration in the most important cities for the spread of the dengue epidemics is clear.

According to Barbosa et al (2012), population density may also have contributed to the establishment of the epidemics. An example of this may be seen in the work of Azevedo (2013), in the Administrative Region of Campinas. This latter author emphasizes that the most populous cities of that area are the places where the greatest degree of environmental insalubrity for dengue is found.

The fact which can explain this insalubrity is related to the circulation of the virus and the geographical proximity to urban areas. As these areas are conurbations, one sees the creation of a single urban agglomeration which abolishes geographical barriers as it facilitates the movement of people who live in municipalities distant from those in which they work, thus intensifying the outbreak of dengue epidemics (AZEVEDO, 2013).

From the geographical point of view, this fact highlights the importance of urban and environmental planning addressed to sanitary and health questions as both the size of the population and the proximity of cities may be directly associated with the occurrence of dengue. These aspects emphasize and confirm the observations of the WHO (2009) for the American continent, which describe a cyclic pattern for dengue epidemics varying between 3 and 5 years.

These facts corroborate the results presented here whereby the process of the diffusion of dengue epidemics in the state of São Paulo, in the period from 2000 to 2015, possesses a pattern of outbreaks, because the fronts of the expansion of the disease in the state of São Paulo are not continuous. The map of the probability of the occurrence of outbreaks shows that there exist epidemic areas in more central cities which diverged from the general tendency shown by the surface tendency map. We may thus demonstrate that the occurrence of epidemic outbreaks of dengue in the territory of the São Paulo state presents a direction, beginning in hotter areas of the state, on the Western Plateau (Planalto Ocidental) and along the coast of the state moving in the direction of the colder areas such as the Atlantic Plateau (Planalto Atlântico), the ranges of the Serra do Mar, of the Mantiqueira and the Heights of the Paranapanema (Alto do Paranapanema). 


\section{FINAL CONSIDERATIONS}

The results here presented and discussed permit us a visual understanding of the dynamics of dengue in the state of São Paulo, because the maps present, in an easily understandable manner, a great deal of important information which is not generally presented systematically in tables and numbers, because the use of the analysis of surface tendency is important to bring out the direction of the epidemic outbreaks of dengue, showing itself to be efficient in the exploratory analysis and in the reflection on particular hypotheses.

Further, by means of the use of the krigagem technique it has been possible to ascertain the areas of greater probability of the occurrence of this ailment, identifying the core areas of the epidemics, revealing the places of epidemic peaks.

Thus, these results will also be of value to public managers in their decisionmaking seeing that these map products can indicate with greater precision the places in which the actions of the fight against dengue should be accorded priority with a view both to mitigating and reducing the transmission of the disease in the state of São Paulo.

These results can also be used by public managers in directing educational actions which have links to and meaning for the target-publics, mobilizing for this purpose both civil society and public administration regarding their joint responsibility in the fight against the mosquito Aedes aegypti and against the dissemination of Dengue, Chikungunha fever and Zika, recently introduced into the state of São Paulo.

\section{ACKNOWLEDGMENTS}

MAMS acknowledges FAPESP (Grant 2014/26229-7) for financial support.

\section{REFERENCES}

ALI, M. et al. Use of a geographic information system for defining spatial risk for dengue transmission in Bangladesh: role for Aedes albopictus in an urban outbreak. American Journal of Medicine and Hygiene. v. 6, n. 69, p. 634-640, 2003.

ARAUJO, J. R.; FERREIRA, E. F.; ABREU, M. H. N. G. Revisão sistemática sobre estudos de espacialização da dengue no Brasil. Revista Brasileira de Epidemiologia. v. 11, n. 4, p. 696-708, 2008.

AZEVEDO, T. S Salubridade ambiental dos municípios da Região Administrativa de Campinas (RADCAMP) no Estado de São Paulo - Brasil: um estudo de caso em relação às epidemias de dengue. In: ENANPEGE 10, Campinas, de 7 a 19 de outubro de 2013. Anais... Campinas: ANPEGE, 2013. p. 5688-5699.

BARBOSA, G. L.; DONALÍSIO, M. R.; STEPHAN, C.; LOURENÇO, R. W.; ANDRADE, V. R.; ARDUINO, M. B.; LIMA, V. L. C. Spatial distribution of the risk of dengue and the entomological indicators in sumaré, State of São Paulo, Brazil Plos Neglected Tropical Diseases v. 8, n. 5, p. e2873, 2014. 
BARBosA, G., L.; hOlCMAN, M., M.; PEREIRA, M.; GOMES, A., H., A.; WANDERLEY, D., M., V. Indicadores de infestação larvária e influência do porte populacional na transmissão de dengue no Estado de São Paulo, Brasil: um estudo ecológico no período de 2007-2008. Epidemiologia e Serviço de Saúde v. 21, n. 2, p. 195-204, 2012.

BARBOSA G. L; LOURENÇO R. W. Análise da distribuição espaço-temporal de dengue e da infestação larvária no município de Tupã, Estado de São Paulo. Revista da Sociedade Brasileira de Medicina Tropical. Rio de Janeiro: v.43, n.2. p.145-151, 2010.

BARCELLOS, C; LOWE, R; Expansion of the dengue transmission area in Brazil: the role of climate and cities. Tropical Medicine e International Health v.19. p 159 168. 2014. doi: 10.1111/tmi.12227.

BARCELLOS, C.; PUSTAI, A. K.; WEBER, M. A.; BRITO, M. R. V. Identificação de locais de transmissão de dengue em Porto Alegre através de técnicas de geoprocessamento. Revista da Sociedade Brasileira de Medicina Tropical. Rio de Janeiro. v. 38. p. 246-250, 2005.

BRASIL Programa Nacional de Combate a Dengue. Brasília: FUNASA. 2002. 32p. CAMARA, F. P.; THEOPHILO, R. L. G.; SANTOS, G. T.; PEREIRA, S. R. F.G. P.; CAMARA, D. C. P.; MATOS, R. R. C. Estudo retrospectivo (histórico) da dengue no Brasil: características regionais e dinâmicas. Revista da Sociedade Brasileira de Medicina Tropical. v. 40. n. 2. p. 192-196, 2007.

CÂMARA, F. P.; GOMES, A. F.; SANTOS, G. T.; E PORTELA CÂMARA, D. C. P. Clima e epidemias de dengue no Estado do Rio de Janeiro. Revista da Sociedade Brasileira de Medicina Tropical. v. 42, n. 2. p. 137-140, 2009.

CARVALHO, M. S.; CÂMARA, G. Análise de eventos pontuais. In: DRUCK, S. et al. (Ed) Análise Espacial de Dados Geográficos, Planaltina: EMBRAPA, 2004. 209p.

CATÃO, R. C. Dengue no Brasil: abordagem na escala nacional. São Paulo: Cultura Acadêmica. 2012. 175p.

CATÃO, R. C.; GUIMARÃES R. B.Tipologia do dengue no Estado de Saõ Paulo. In: ENANPEGE 10, Campinas, de 7 a 19 de outubro de 2013. Anais... Campinas: ANPEGE, 2013. p. 5856 a 5866.

CONSOli, R. A. G. B., OliveirA, R. L. Principais mosquitos de importância sanitária no Brasil. Rio de Janeiro: Editora Fiocruz, 1998.

DUQUE, J. E.; SILVA, R. V.; KUWABARA, E. F.; NAVARRO-SILVA, M. A. Dengue no Estado do Paraná, Brasil: distribuição temporal e espacial no período 1995-2007. Revista Salud de la Universidad Industrial de Santander v. 42, n. 2, p. 113$122,2010$.

FAVARO, E. A.; DIBO, M. R.; PEREIRA, M.; CHIEROTTI, A. P.; RODRIGUES-JUNiOR, A. L.; CHIARAVALLOTI-NETO, F. Aedes aegypti entomological indices in an endemic area for dengue in São Paulo State, Brazil. Revista de Saúde Pública v. 47, n. 3, p. 588597, 2013.

FERREIRA, A. C.; CHIARAVALLOTI NETO, F. Infestação de área urbana por Aedes aegypti e relação com níveis socioeconômicos. Revista de Saúde Pública. São Paulo. v. 41, p. 915-922, 2007.

FERREIRA, M. C. Procedimento metodológico para modelagem cartográfica e analise regional de epidemias de dengue em sistema de informação geográfica. 2003. 231 f. Tese (Livre Docência e Geografia), Departamento de Geografia. Instituto de Geociências. Universidade Estadual de Campinas, Campinas, 2003. 
FLAUZINO, R. F.; SOUZA-SANTOS, R; BARCELLOS, C.; GRACIE, R. MAGALHÃES, M. A.; OLIVEIRA, R. M. Spatial heterogeneity of dengue fever in local studies, City of Niterói, Southeastern Brazil. São Paulo: Revista de Saúde Pública, v. 43, n. 6, p. 18, 2009.

FORATTINI, O. P. Culicidologia médica. Vol. 2. São Paulo: Edusp, 2002. 860p.

FOTHERRINGHAM, A. S. et al. Quantitativegeography.Londres: Sage. 2000. 270p.

GLASSER, C., M.; GOMES, A., C. Infestação do Estado de São Paulo por Aedes aegypti e Aedes albopictus São Paulo: Revista de Saúde Pública. v. 34, n. 6, p. 570-577. 2000.

GLASSER, C., M.; GOMES, A., C. Clima e sobreposição da distribuição Aedes aegypti e Aedes albopictus na infestação do Estado de São Paulo. São Paulo: Revista de Saúde Pública. v. 34, n. 6, p. 570-577, 2002.

GOLDEN SOFTWARE. Surfer for windowns version 6.0: user's guide. Colorado: Golden Software. 1995.

HINO, P.; VILLA, T. C.S.; SASSAKI, C. M.; NOGUEIRA, J. A.; SANTOS, C. B. Geoprocessamento aplicado à saúde. Ribeirão Preto: Revista Latino-Amaricana de Enfermagem. v. 14, n. 16. p. 939-943, 2006.

HEUKELBACH, J.; OLIVEIRA, F. A. S.; KERR-PONTES, L., R., S.; FELDMEIER, H. Risk factors associated with an outbreak of dengue dever in a favela in Fortaleza, northeast Brazil. Tropical Medicine and International Health. v. 6, n. 8, p. 635-642, 2001.

ISAAKS, E. H.; SRIVASTAVA, R. M. An Introduction to Applied Geostatistics. Oxford University Press. 1989. 561p.

LAFFERTY, K. D. The ecology of climate change and infectious diseases. Ecology. n. 90, v. 4, p. 888-900, 2009.

LAURENTI, R.; GOTLIEB, M. J. Estatísticas de saúde. 2a Edit. São Paulo: EPU, 1987. $186 \mathrm{p}$.

LAWSON, A. B. Bayesian disease mapping: hierarchical modeling in spatial epidemiology. Danvers: Taylor and Francis Press. 2009. 344p.

MONDINI, A.; CHIARAVALLOTTI NETO, F. Variáveis sócioeconômicas e a transmissão de dengue. Revista de Saúde Pública. São Paulo. v. 41, p. 923-930, 2007.

PIOVEZAN, R., AZEVEDO, T. S, ACORINTHE J. P. O., POLIZELLI, N.; VISOCKAS, A; CANTEIRO, C. L., VON ZUBEN, C. J. Perfil epidemiológico e análise espacial do risco da dengue da área urbana de Santa Bárbara d'Oeste - SP, durante o período de 1995 a 2010. Geografia, v. 39, n. 3, p. 525-539, 2013.

SÃO PAULO - CVE - Centro de Vigilância Epidemiológica do Estado de São Paulo Dengue: Dados Estatísticos. 2015 Disponível em: http://www.cve.saude.sp.gov.br/ htm/zoo/dengue_dados.html. Acesso: 25 de Fevereiro de 2015.

SÃO PAULO Programa de vigilância e controle da dengue. São Paulo: Secretaria de Estado da Saúde de São Paulo. 2010. 65 p.

SIQUEIRA JR, J. B.; VINHAL, L. C.; SAID, R. F. C.; HOFFMANN, J. L.; MARTINS, J.; BARBIRATTO, S. B.; COELHO, G. E. Dengue no Brasil: tendências e mudanças na epidemiologia, com ênfase nas epidemias de 2008 e 2010. Brasília: Secretaria de Vigilância em Saúde, Programa Nacional de Controle da Dengue, Brasil. 2010. 171 p. SOUZA, L. J. Dengue: diagnóstico, tratamento e prevenção. Rio de Janeiro: Editora Rubio, 2a Edit. 2008. 248p. 
YAMAMOTO, J. K.; LANDIM, P. M. B. Geoestatística: conceitos e aplicações. São Paulo: Oficina de Textos. 2013. 215 p.

WALDMAN, E. A. Vigilância em Saúde Pública. Série Saúde e Cidadania, v. 7: São Paulo: Faculdade de Saúde Pública da Universidade de São Paulo, 1998. 255p.

WATTS D. M.; BURKE, D. S. HARRISON B. H. Effect of temperature on the vector efficiency of Aedes aegypti for dengue 2 virus. The American Journal of Tropical Medicine and Hygiene v. 36, p. 143-152, 1987.

Recebido em agosto de 2016 Revisado em novembro de 2016 Aceito em janeiro de 2017 